\title{
Corporate Social Responsibility for Sustainable Development of Small and Medium Enterprises in Vietnam
}

\author{
Do Hai Hung**, Nguyen Thi Hanh Nguyen \\ Faculty of Business Management, Hanoi University of Industry, Hanoi, Vietnam
}

Email address:

dohaihung@haui.edu.vn (Do H. Hung)

${ }^{*}$ Corresponding author

To cite this article:

Do Hai Hung, Nguyen Thi Hanh Nguyen. Corporate Social Responsibility for Sustainable Development of Small and Medium Enterprises in Vietnam. Journal of Business and Economic Development. Vol. 5, No. 3, 2020, pp. 157-163. doi: 10.11648/j.jbed.20200503.15

Received: July 9, 2020; Accepted: July 27, 2020; Published: August 10, 2020

\begin{abstract}
Implementing social responsibility activities (CSR) towards sustainable development (Sustainable Development) is one of the issues that businesses pay special attention. The study carried out a survey of 316 small and medium sized enterprises allocated according to different business sectors and territories in Vietnam. The main purpose of the study is to assess the impact of corporate social responsibility compared to other factors developed in the research model affecting the sustainable development of small and medium enterprises (SMEs) in Vietnam. The observations constructed by research team and inserted in the corporate social responsibility policy scale are: Participation in vocational training support programs in the community; Building programs on clean water and sanitation; Training and improving the capacity and social knowledge for workers; Contributing to social activities in the locality; Paying attention to issues of environmental pollution treatment; and finally complying with the provisions of law to ensure food hygiene and safety and environment. The authors applied regression analysis to assess the impact of corporate social responsibility policies on sustainable development of small and medium-sized enterprises (SMEs). The research results showed that the social activities of enterprises have a positive influence on the sustainable development of small and medium-sized enterprises in Vietnam, besides other factors such as: Enterprise management capacity, finance, human resources and support policies from the government.
\end{abstract}

Keywords: Sustainable Development, Small and Medium Enterprises, Social Responsibility

\section{Introduction}

Facing the trend of extensive international integration, the issue of sustainable development in general and enterprise's sustainable development in particular in recent years has always been given special attention by state management agencies. Implementing sustainable development is the responsibility of the whole society, including the contribution of the enterprise community. However, to further promote the development of enterprises towards sustainability, the role of the enterprise's CSR activities should be considered [1].

In Vietnam, according to the annual report of Vietnam Enterprises 2018/2019 of Vietnam Chamber of Commerce and Industry (VCCI) in terms of classification of small and medium-sized enterprises according to the Government's Decree No. 39, according to the labor size: Medium enterprises with the number of 8,518 enterprises, accounting for $1.58 \%$; small enterprises with the number of 115,235 enterprises, accounting for $21.35 \%$; and micro enterprises with the number of 415,835 enterprises, accounting for $77.07 \%$. The proportion of SMEs now accounts for $97.8 \%$ of the total number of enterprises in Vietnam [2-4].

The characteristics of SMEs are the limited amount of products, mainly base on manual labor, SMEs, usually only sell a few products and services in compliance with the qualifications and experience as well as finance capacity of business owners; The business capital of SMEs is mainly owned by the business owners, or borrowed from business owners relatives and friends, and the ability to access capital from credit institutions is low; SMEs are flexible due to low initial investment, use few labor and local resources. Therefore, SMEs can easily change their production plans, convert their business premises, change their business type and even easily dissolve their businesses; SMEs are established and operated mainly based on the capacity and experience of the business owners themselves, so the organization of the apparatus is very 
compact and management decisions are also quickly implemented [5]. Stemming from the characteristics of SMEs in Vietnam today, it can be seen that, in the long term, the sustainable development of small and medium enterprises in Vietnam is necessary and consistent with the general development trend of the world when international integration in countries are more extensive. The inherent characteristics of SMEs in Vietnam currently mentioned above such as: limited capital, backward production technology, poor infrastructure will heavily affect labor productivity or problems in addressing environmental pollution and contribute to the overall development of society [6]. These barriers need to be thoroughly overcome in order to promote the small and medium enterprises in Vietnam towards sustainable development.

The development of enterprises depends on available resources, the issue of community benefits, solving environmental pollution in the production process is really necessary for businesses. In order to promote small and medium-enterprises in Vietnam maintaining and developing towards sustainable development, study that assess the impact and impact level of CSR policies to the sustainable development of small and medium - sized enterprises is essential in the current situation of SME in Vietnam. Through the research results, the author proposes a number of solutions and recommendations for enterprises and state management agencies to maintain and promote the sustainable development of SMEs on a wider scale and more quality.

\section{Literature Review}

Sustainable development of enterprises in general and sustainable development of small and medium-sized enterprises in particular always paid special attention of researchers in the context of the more extensive international integration. According to Atkinson et al. (1999), there are 6 target systems for sustainable development, divided into 3 groups which are Human system; Support system; and Natural system. In which: "Human system=personal development + social system + government system"; "Support system=economic system + infrastructure system"; "Natural system=environment and resource system" [7]. Understanding sustainable development also plays an important part in the theory of sustainable development, including an analysis of the relationship between society and the environment; Sustainable development and government administration; tools and systems for sustainable development; outline of a sustainable society [8].

As for the Corporate Social Responsibility (CSR) policy, first published in 1953 by HRBowen, the policy was designed to propagate and appeal to managers stop harming the rights and benefit of others, calling for charity to compensate for damages caused by businesses that harm society. Since then, the term corporate social responsibility has been interested by many researchers and given different points of view. D. Wood (2010) said that CSR is difficult to define, different objects understand different CSR. Each industry, organization, and government views CSR from a different point of view, so there are many different definitions of corporate $\operatorname{CSR}[9,10]$. Despite the lack of a consistent definition, all definitions show that the company should meet social expectations when planning environmental management strategies [11]. Carroll (1979, 1991) stated that: "Social responsibility is all the economic, legal, ethical and charitable issues of an organization that society expects from a given time." This is a concept that has been widely used in social responsibility studies, depending on which organization an administrator can choose from among the four levels [12, 13]. Another common concept of the European Commission's corporate social responsibility (European Commission, 2001) is that businesses integrate social and environmental concerns into their businesses - interact with stakeholders on a voluntary basis [14]. From a sustainable social perspective, the relationship of corporate social responsibility policies to the sustainable development of enterprises in general, small and medium-sized enterprises in particular, needs to be assessed and considered in detail.

Carroll (1996) found that CSR in businesses consists of four main types of responsibilities, including legal responsibility, economic responsibility, ethical responsibility, and charity responsibility [12]. Although all businesses have these four responsibilities, most of these components are not implemented in a uniform and complete manner (Birch, 2002). Because the content of the CSR concept is quite complex and broad, it has an open rule that represents business relationships with society and is a dynamic concept (Matten and Crane, 2005; Carroll, 1999). On the same topic, Jenkins (2004) acknowledges that CSR activities in SMEs are less common and often have no clear implementation strategy compared to large-scale enterprises.

Mujahid and Abdullah (2014) pointed out that CSR has a positive and significant influence on the financial performance of businesses as well as the wealth of shareholders. In this same view, Kiran et al. (2015) emphasized, there exists a close relationship between social responsibility and profitability of enterprises; The study identified three main issues: (i) social responsibility has a positive impact on net profit and net profit margin; (ii) social responsibility has a negative impact on the total assets of the enterprise; and (iii) social responsibility has no significant effect on the profitability of the business.

Research by Duygu Turker (2008) [15] stated that social responsibility included the following components: CSR for social and non-social stakeholders (e.g. Environment or future generation), CSR for employees, CSR for customers and CSR for the government. According to him, the social activities of businesses related to these components would affect the level of employee engagement with the organization through social identity theory (SIT). Research results showed that CSR for employees has the greatest impact on employee engagement with the organization because it is related to careers, training opportunities, equality and working environment. CSR for customers has the second highest level of influence because it relates to the image of the organization, thus affecting the pride of the employees for the organization. Next is CSR for 
stakeholders (social and non-social). Finally, social responsibility to the government. Social responsibility will also create credibility for businesses with customers, investors suppliers and governments. Thereby positively influencing decision making in favor of SMEs. CSR also brings competitive advantages, thereby affecting the efficiency of business operations of the organization. Organizations can enhance employee engagement by promoting socially beneficial activities [16].

In addition, there are a number of other studies showing that social responsibility has a positive influence on the business results of SMEs such as Kakakhel et al (2014), Siddiq and Javed (2014), Palmer (2012), Babola. (2012), Malik and Nadeem (2014), Raihan et al (2015), Khan et al (2016), Akanbi and Ofoegbu (2012), Monsuru and Abdulazeez (2014), Weshah et al (2012), Ahamed et al. (2014), Yusoff and Adamu (2016), and Ozcelik et al. (2014) [17].

Research by Le Ngoc Nuong (2018) [18] used a linear structure model (SEM) to identify and evaluate the influence of factors that are barriers affecting the development of small and medium-sized industrial enterprises. In Thai Nguyen province of Vietnam, research showed that the local supporting policy factor creates a greater barrier than the human resource factor, material source and corporate social responsibility, in addition to the financial capacity factors and access to finance. Or the study of Mashenece et al. (2014) with the scope of research in African countries, using multivariate regression models showed the growth and development potential of SMEs depending on advantageous business environment. However, most countries in Africa are facing many challenges that may hinder their growth potential, including the good performance of corporate social responsibilities in local. The study also emphasized that the Government needs to set specific policies to support and promote businesses to participate more actively in the implementation of social responsibility in the community.

In general, the basic studies have emphasized the role of the implementation of social responsibility for the development and sustainable development of small and medium sized enterprises. Considering the scope of research in Vietnam, this issue has not been reviewed and evaluated in detail. Therefore, this study is necessary to assess the role and impact of social responsibility performance compared to other factors affecting the sustainable development of small and medium-sized enterprises (SMEs). in Viet Nam.

\section{Research Methods}

\subsection{Data Collection Methods}

Collecting secondary data through published articles and research works related to domestic and foreign research topics to clarify the urgency of the topic.

Collecting primary data through in-depth interviews with experts and managers in small and medium-sized enterprises in Vietnam to develop an official questionnaire, then use a convenient sampling method to survey collected feedback data of business managers on the impact of corporate social responsibility activities on SMEs sustainable development in Vietnam. The questionnaire uses the Rennis Likert scale (also known as the Likert scale), the Likert scale with 5 levels of low to high scores, ranging from 1-5 as follows: 1 . Strongly disagree; 2. Disagree; 3 . Normal; 4. Agree; 5. Strongly agree.

The total number of votes issued was 350 , collecting 331 votes, the number of valid votes for data processing was 316 votes.

\subsection{Data Processing Method}

Primary data, after being collected, was processed in SPSS 23.0 software. The study tested the reliability of a scale using Cronbach's Alpha coefficient, which is a statistical test of the degree of rigor with which the items in the scale correlate. Then, conduct Exploratory Factor Analysis (EFA) to check the unidirectionalness of the scales in the study. Finally, the study uses multivariate regression methods to evaluate the impact of the operational factors of social responsibility implementation of enterprises compared to the following factors: Supporting the policies of enterprises of the Government; Enterprise management capacity and resources of enterprises to the sustainable development of small and medium enterprises in Vietnam.

\subsection{Research Models}

Research hypotheses:

Hypothesis H1: The Government supporting policy element has a positive influence on the sustainable development of SMEs in Vietnam.

Hypothesis H2: Factors of enterprise management capacity, positively affecting the sustainable development of SMEs in Vietnam.

Hypothesis H3: Operational factors of corporate social responsibility have a positive influence on the sustainable development of SMEs in Vietnam.

Hypothesis H4: The resources of enterprises have a positive influence on the sustainable development of SMEs in Vietnam.

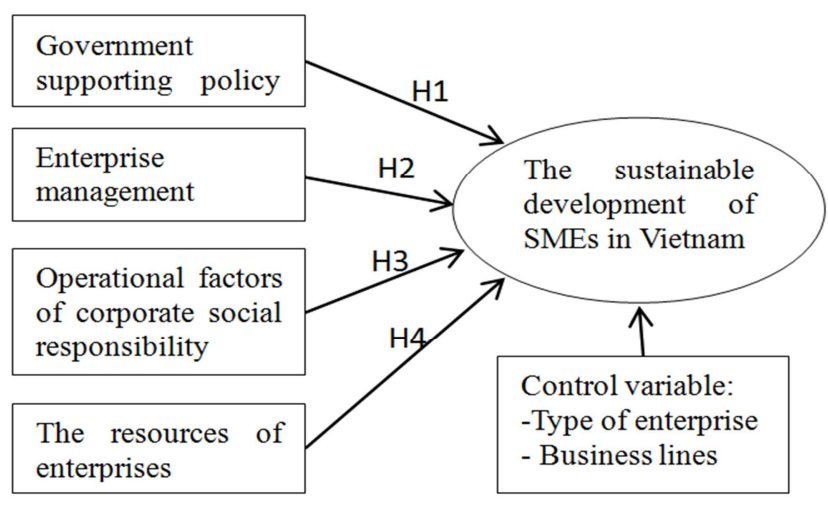

Figure 1. Research model.

The scale

The scales in the study are described in detail in Table 1. 
Table 1. Measurement scale and source to construct the scale.

\begin{tabular}{|c|c|c|c|}
\hline Scale & Encode & Question & Source \\
\hline \multirow{6}{*}{$\begin{array}{l}\text { Government } \\
\text { supporting policy }\end{array}$} & CS1 & Accessing the production premises easily & \multirow{6}{*}{$\begin{array}{l}\text { Le Ngoc Nuong (2018) } \\
\text { [18] and Author's } \\
\text { proposal }\end{array}$} \\
\hline & CS2 & Supported to participate in social activities & \\
\hline & CS3 & No difficulty in handling administrative procedures & \\
\hline & CS4 & Preferential tax policies in production and business activities & \\
\hline & CS5 & Enterprises are informed the change of environmental protection policy promptly & \\
\hline & CS6 & Accessing credit resources supported by the Government easily & \\
\hline \multirow{6}{*}{$\begin{array}{l}\text { Operational factors of } \\
\text { corporate social } \\
\text { responsibility }\end{array}$} & TN1 & Participating vocational training programs for young people in the community & \multirow{6}{*}{$\begin{array}{l}\text { Phan Van Dan (2012) } \\
\text { [19]; Duyg u. T (2008); } \\
\text { Mujahid. A (2014) [15] } \\
\text { and Author's proposal }\end{array}$} \\
\hline & TN2 & Participating in construction of clean water and sanitation programs for the community & \\
\hline & TN3 & Participating in training, improving capacity and social knowledge for the workers & \\
\hline & TN4 & Participating in contribution of social activities in the locality & \\
\hline & TN5 & Focusing and paying attention on issues of environmental pollution treatment & \\
\hline & TN6 & Complying with the provisions of the law on ensuring food and environmental safety & \\
\hline \multirow{5}{*}{$\begin{array}{l}\text { The resources of } \\
\text { enterprises }\end{array}$} & NL1 & Current financial resources are sufficient to expand business activities & \multirow{5}{*}{$\begin{array}{l}\text { Umar Ibrahim } \\
\text { (2008)[20] and Trinh } \\
\text { Duc Chieu (2010) [5] }\end{array}$} \\
\hline & NL2 & Current financial resources are sufficient to sustain the business activities & \\
\hline & NL3 & Human resources in enterprises have good working capacity & \\
\hline & NL4 & Annually, the number of qualified employees in the enterprise is becoming higher and higher & \\
\hline & NL5 & After training, labor is more productive & \\
\hline \multirow{4}{*}{$\begin{array}{l}\text { Enterprise } \\
\text { management capacity }\end{array}$} & QL1 & The management apparatus of the enterprise has all the skills of business administration & \multirow{4}{*}{$\begin{array}{l}\text { Asma Benzazoua } \\
\text { Bouazza (2015) and } \\
\text { Sefiani (2013) [21] }\end{array}$} \\
\hline & QL2 & The management apparatus of the enterprise is fully qualified to manage and run the business & \\
\hline & QL3 & Every year, managers participate in training programs to improve management capacity & \\
\hline & QL4 & Enterprises have access to training programs to support management capacity & \\
\hline \multirow{6}{*}{$\begin{array}{l}\text { The sustainable } \\
\text { development of } \\
\text { SMEs in Vietnam }\end{array}$} & BV1 & Enterprises always have high profits and grow steadily every year & \multirow{6}{*}{$\begin{array}{l}\text { Phan Van Dan (2012) } \\
\text { [19] and Author's } \\
\text { proposal }\end{array}$} \\
\hline & BV2 & Enterprises can expand production and business markets & \\
\hline & BV3 & Enterprises are recorded for environmental protection in production & \\
\hline & BV4 & Enterprises have made positive contributions to local environmental protection activities & \\
\hline & BV5 & $\begin{array}{l}\text { Enterprises are always highly appreciated by local agencies for their contribution to local } \\
\text { social activities }\end{array}$ & \\
\hline & BV6 & Enterprises always create motivation to work for labor & \\
\hline
\end{tabular}

\section{Research Results}

\subsection{Descriptive Statistics Research}

Table 2. Number of surveyed enterprises by industry and scale.

\begin{tabular}{llllll}
\hline Scale Business lines & Super small & Small & Medium & Total & Proportion by industry (\%) \\
\hline Agriculture-forestry-fishery & 16 & 19 & 7 & 42 & 13,3 \\
Industry and Contribution & 35 & 66 & 30 & 131 & 41,5 \\
Trade and services & 40 & 72 & 31 & 143 & 45,2 \\
Total of enterprises & 91 & 157 & 68 & 316 & 100 \\
Proportion of scale (\%) & 28,8 & 49,7 & 21,5 & 100 & 100 \\
\hline
\end{tabular}

Note: Research sample statistics of the authors.

The survey results of the above small and medium-sized enterprises in Vietnam by industry and scale are presented in detail in Table 2. Out of 316 valid survey questionnaires, the number of small and medium-sized enterprises in the trade and services sector accounted for the largest proportion $(45.2 \%)$; The number of enterprises in agriculture-forestry-fishery sector accounts for the least proportion (13.3\%).

\subsection{Verify the Reliability of the Scale}

The scales are assessed for reliability through Cronbach's Alpha coefficient. The results of calculating this coefficient indicate that 4 groups of factors have Cronbach's Alpha coefficient greater than 0.6 (Table 3).
All observed variables have correlated-total variables $>0.4$. Therefore, the factor scales affecting the sustainable development of small and medium enterprises in Vietnam are eligible for EFA analysis.

\subsection{Exploratory Factor Analysis EFA}

The results of the EFA discovery factor analysis all factors affecting the sustainable development of SMEs in Vietnam for the value of KMO (Kaiser-Meyer-Olkin) $=0.7128>0.6$. Therefore, factor analysis is consistent with the research data obtained. The Bartlett's test value with the hypothesis ( $\mathrm{H} 0)$ is "non-correlated variables" with the value $\mathrm{Sig}=0.00<0.05$.

After conducting EFA discovery factor analysis, 6 factor groups were extracted from 26 indicators. The result of data 
processing for Eigenvalues value $=1,162>1$, so it can be confirmed that the number of factors extracted is appropriate. Total Variance Explained of factor analysis is 58,241\%>50\%. This means that the extracted factors account for $58,241 \%$ of the observed variables included in the EFA analysis.
The results of EFA analysis show that the enterprise resource factor group is extracted into 2 separate groups of factors: NL1, NL2: financial resources and NL3, NL4, NL5: human resources.

Table 3. EFA factor analysis results and assessment of reliability of the scale.

\begin{tabular}{|c|c|c|c|c|c|c|}
\hline \multirow{2}{*}{ Factors } & \multicolumn{6}{|c|}{ Factor Loading } \\
\hline & 1 & 2 & 3 & 4 & 5 & 6 \\
\hline Cronbach's Alpha & 0.761 & 0.724 & 0.753 & 0.699 & 0.817 & 0.778 \\
\hline QL3 & 0.811 & & & & & \\
\hline QL2 & 0.775 & & & & & \\
\hline QL1 & 0.754 & & & & & \\
\hline QL4 & 0.706 & & & & & \\
\hline $\mathrm{CS} 2$ & & 0.781 & & & & \\
\hline $\mathrm{CS} 3$ & & 0.772 & & & & \\
\hline CS1 & & 0.741 & & & & \\
\hline CS4 & & 0.702 & & & & \\
\hline CS6 & & 0.682 & & & & \\
\hline CS5 & & 0.665 & & & & \\
\hline TN2 & & & 0.816 & & & \\
\hline TN3 & & & 0.785 & & & \\
\hline TN1 & & & 0.767 & & & \\
\hline TN6 & & & 0.752 & & & \\
\hline TN5 & & & 0.712 & & & \\
\hline TN4 & & & 0.684 & & & \\
\hline NL1 & & & & 0.725 & & \\
\hline NL2 & & & & 0.672 & & \\
\hline NL3 & & & & & 0.845 & \\
\hline NL4 & & & & & 0.826 & \\
\hline NL5 & & & & & 0.785 & \\
\hline BV1 & & & & & & 0.826 \\
\hline BV3 & & & & & & 0.801 \\
\hline BV4 & & & & & & 0.778 \\
\hline BV2 & & & & & & 0.762 \\
\hline BV5 & & & & & & 0.725 \\
\hline
\end{tabular}

Note: Results of data analysis through SPSS 23.0.

\subsection{Regression Analysis}

Regression analysis value of $\mathrm{R}=$ results in the 0.612 and adjusted R2 is 0.604 . This means that the relationship between the independent variables explains $60.4 \%$ of the dependent variable as "Sustainable development of small and medium enterprises in Vietnam". Through ANOVA analysis results, the value of $F=60,412$ with statistical significance $\mathrm{Sig}=0.001$
$<0.05$. It can be confirmed the existence of relationships between independent variables and dependent variables. Thereby, showing that the research model ensures reliability.

Based on the Beta coefficient in Table 4, it can be seen that the factors in the research model, the human resources factor $(\mathrm{NL})$ have the largest Beta standardization factor $=0.256$.

Table 4. Beta coefficients after performing regression.

\begin{tabular}{|c|c|c|c|c|c|}
\hline \multirow{2}{*}{ (Constant) } & \multicolumn{2}{|c|}{ The coefficient is not standardized } & \multirow{2}{*}{$\begin{array}{l}\text { Standardized coefficient } \\
\text { Beta }\end{array}$} & \multirow{2}{*}{ Testing value $t$} & \multirow{2}{*}{ Level of significance Sig } \\
\hline & B & Standard error & & & \\
\hline & $-1,312$ & 0,265 & & $-3,252$ & 0,000 \\
\hline NL & 0,535 & 0,046 & 0,256 & 5,455 & 0,000 \\
\hline CS & 0,471 & 0,032 & 0,165 & 5,311 & 0,001 \\
\hline QL & 0,126 & 0,031 & 0,239 & 3,562 & 0,005 \\
\hline $\mathrm{TC}$ & 0,112 & 0,036 & 0,235 & 3,258 & 0,012 \\
\hline $\mathrm{TN}$ & 0,248 & 0,056 & 0,189 & 5,341 & 0,021 \\
\hline
\end{tabular}

Note: Results of data analysis through SPSS 23.0.

The policy support element of the Government (CS) has the lowest Beta coefficient $=0.165$. Sig value. of all variables $<0.05$. Therefore, the hypotheses $\mathrm{H} 1, \mathrm{H} 2, \mathrm{H} 3$ and $\mathrm{H} 4$ proposed in the research model are all accepted. The non-standardized regression model of the factors affecting the sustainable development of small and medium enterprises in Vietnam is determined as follows: 
$\mathrm{BV}=-1,312+0,256 * \mathrm{NL}+0.235 * \mathrm{TC}+0.189 * \mathrm{TN}+0.165 *$

$$
\mathrm{CS}+0.223 * \mathrm{QL}
$$

Based on the regression equation (1), it can be seen that the human resource factor (NL) has the greatest impact on the sustainable development of small and medium enterprises in Vietnam. Next are the factors of enterprise management capacity (QL), factor of financial resources (TC), Activities of social responsibility (TN) and finally the support policy of the Government (CS). It can be seen that the corporate social responsibility activity has a positive influence and the third most powerful factor in the author's research model, behind human resource factors, enterprise management capacity and finance.

\section{Conclusions}

The research results show that the social activities of enterprises have a positive influence on the sustainable development of SMEs in Vietnam with the coefficient $\beta=0.189$. This proves that the corporate social responsibility activities play an important role in promoting Vietnamese SMEs towards sustainable development. Therefore, through the research results, the authors propose a number of solutions and recommendations for the policies on corporate social responsibility for the sustainable development of SMEs in Vietnam, specifically as follows:

Firstly, businesses need to build a system of specific rules and regulations on the salary and bonus regime for employees, ensuring fairness in the company. Besides, it is necessary to create a safe working environment in the aspects of food safety, fire safety, fire safety and human rights.

Secondly, strengthening the deployment of supporting activities and associating training with educational and training institutions to improve the quality of local human resources and human resources in enterprises. Business managers must be a bridge between local human resources, human resources in enterprises and quality education and training institutions to coordinate the deployment of more training courses for knowledge and skills for workers, thereby promoting the quality of human resources in the community of businesses and localities more and more developed.

Third, strengthen the role of the SME Association in Vietnam and to promote the development and cohesion between SMEs. Supporting and promoting the propaganda and education for businesses about social responsibility and the meaning of local social activities. In addition, through these associations, businesses can timely access new policies, new legal documents of the State on sustainable development.

Fourthly, the state management agencies need to build more legal corridors that force businesses to implement social responsibilities, considering the implementation of social responsibility as a mandatory regulation so that businesses can enjoy preferential policies from the Government.

Fifth, the State management agencies from the central to local levels, the Association of SMEs should honor and recognize the enterprises that perform well social responsibility annually. Such recognition will be the driving force for businesses to perform better corporate social responsibility, which is an important foundation for the sustainable development of businesses.

\section{References}

[1] Baker. S, 1997. The Politics of Sustainable Development. London, Routledge.

[2] General Statistics Office of Vietnam, 2019.

[3] Viet Nam Enterprises Law, 2014. No. 68/2014/QH13.

[4] Ministry of sustainable development targets of enterprises, 2017-2019. Viet Nam Chamber of Commerce and Industry (VCCI).

[5] Trinh Duc Chieu, 2010. The impact factor influence to growth of small and medium enterprises in Viet Nam, Government Economics Research.

[6] Phung The Dong, 2019, Supporting Vietnam's small and medium-sized enterprises in their current development. Finance Journal, No. 11.

[7] Atkinson, 1999. The measurement of sustainable development, Theory and implementation of Economic Models for sustainable Development: 175-193.

[8] Blewitt. J, 2008. Understanding Sustainable Development, Taylor \& Francis Ltd.

[9] Bridger. J, 1999. Toward an Interactional Approach to Sustainable Community Development. Journal of Rural Studies: 15 (4).

[10] Wood, D., 2010. Measuring corporate social performance: A review. International Journal of Management Reviews. 12/1: 20-32.

[11] Gossling, T and Vocht, C., 2007. Social role conceptions and CSR policy success. Journal of Business Ethics. 47/40: 363-372.

[12] Carroll, A. B., 1991. The pyramid of corporate social responsibility: Toward the moral management of organizational stakeholders. Business horizons. 34/4: 39-48.

[13] Carroll, A., 1979. A three-dimensional conceptual model of corporate performance. The Academy of Management Review. 4: 497-505.

[14] Le Phuoc Hung \& Luu Tien Thuan, 2017. Corporate social responsibility - Summarizing some topics and proposing research directions, Scientific Journal, Can Tho University. No. 50: $19-33$.

[15] Duygu. T, 2008. Measuring Corporate Social Responsibility: A Scale Development Study. Journal of Business Ethics, 85, 411-427.

[16] Imran. A, 2010. Effects of Motivational Factors on Employees Job Satisfaction a Case Study of University of Punjab. International Journal of Business and Management, Vol. 5, No. 3.

[17] Herman Daly, 1989. Ecological Economics and Sustainable Development, Edward Elgar Ltd. 
[18] Le Ngoc Nuong, 2018. Factors affecting the development of small and medium industrial enterprises in Thai Nguyen-Viet Nam, Economic and Business Management University.

[19] Phan Van Dan, 2012. Building a scale for enterprise sustainability, Scientific Journal, Can Tho University.

[20] Ibrahim. U, 2008. An analysis of strategic factors affecting the performance of small and medium industries in Borno State of Nigeria. St Clements University, Nigeria.

[21] Bouazza. A, 2015. Small and Medium Enterprises as an Effective Sector for Economic Development and Employment Creation in Algeria, International Journal of Economics, Commer, Vol. 3 (2). 